Litteratur

1. Hexeberg SC. Ny høyesterettsdom om nakke skade. Tidsskr Nor Legeforen 2011; 131: 1804-5.

2. Nakkeslengskade. Diagnostikk og evaluering. SMM-rapport nr. 5/2000. Oslo: Senter for medisinsk metodevurdering, 2000

www.kunnskapssenteret.no/Publikasjoner/ attachment/11054?=true\&_ts=12cc5f03e26 (7.12.2011).

3. Castro WH, Meyer SJ, Becke ME et al. No stress no whiplash? Prevalence of «whiplash» symptoms following exposure to a placebo rear-end collision. Int J Legal Med 2001; 114: 316-22.

4. Schrader H, Stovner LJ, Ferrari R. Kronisk nakkeslengsyndrom -- en oversikt. Tidsskr Nor Lægeforen 2002; 122: $1296-9$

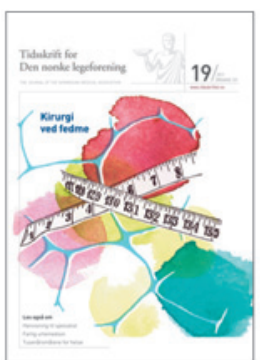

\section{Hjerneslag - tverrfaglig tilnærming}

Ulrike Waje-Andreassen og medarbeidere kommenterte i Tidsskriftet nr. 19/2011 (1) artikkelen til Antje Reichenbach og medarbeidere i Tidsskriftet nr. 9-10/2011, som omhandler organisering av hjerneslagbehandlingen ved Oslo universitetssykehus, Ullevål (2). Til slutt i sin kommentar vektlegger de betydningen av et godt tverrfaglig samarbeid mellom alle spesialiteter innen medisin og nevrologi. Budskapet for øvrig fremstår imidlertid som argumentasjon for at pasienter med mistenkt hjerneslag skal behandles av nevrologer på grunn av behovet for nevrologisk differensialdiagnostikk.

$\mathrm{Vi}$ vil støtte en organisering som beskrevet ved Ullevål der både nevrologer og indremedisinere/geriatere jobber ved samme avdeling. Det sikrer at slagpasientene, som sykdomsmessig befinner seg både under indremedisin og nevrologi, raskt får vurdering av aktuelle spesialister. Dermed kan de kategoriseres med reelle hjerneslag, eller med medisinske eller nevrologiske imitatorer som etter vår erfaring kan utgjøre rundt halvparten av innlagte pasienter. Tilgang til nevroradiologisk kompetanse for differensialdiagnostikk burde være lik uavhengig av avdelingen pasienten er innlagt $i$.

Populasjonen henvist med spørsmål om hjerneslag har en stor andel eldre med hyppig atypisk sykdomspresentasjon, multimorbiditet og multifarmasi, faktorer som gjør geriatrisk kompetanse like viktig som nevrologisk. Flere steder har det vært praktisert aldersskiller i fordelingen av pasienter med mistenkt slag, men dette kan skape uhensiktsmessige forskjeller i rutiner og behandling.

Ved Ålesund sjukehus ligger slagenheten i medisinsk avdeling, styrt av geriatere, men med daglig rask tilgang til nevrologer i de tilfeller der slagdiagnosen ikke er entydig. Nevrolog deltar også i medisinske morgenmøter. Slagenheten tar imot alle aldersgrupper med mistenkt hjerneslag. Det er sterkt fokus på akuttbehandling inkludert trombolytisk behandling og akutt vaskulær utredning inkludert ultralyd, samt overvåking og stabilisering. Med døgnkontinuerlig medisinsk vakt sikres behandlingen av kompliserende tilstander og komplikasjoner. Leger tilknyttet slag og geriatri kan kontaktes utenom vakt for diskusjon. Vi mener at denne organiseringen sikrer både kontinuiteten og akuttfokuset som Waje-Andreassen og medarbeidere etterlyser, og nevrologisk og medisinsk differensialdiagnostikk. Hvilken hovedspesialitet avdelingen ligger under bør ikke være avgjørende, det bør derimot søkelyset på aktiv behandling og utredning av hjerneslag $i$ et samarbeid være.

Vi deler imidlertid bekymringen som reises av Christian Lund i Tidsskriftet nr. 19/2011, over manglende grad av trombolyse ved enkelte sykehus (3). En årsak til forskjeller kan være ulike holdninger på sykehusene, en annen kan være geografiske forhold eller lavt kunnskapsnivå om hjerneslag i befolkningen. Slagmiljøet bør derfor i fellesskap bidra til gjentatt generell informasjon om hjerneslag, slik det nå pågår i region Helse Midt-Norge. Dette er etter vår mening viktigere enn utspill om høyspesialisert behandling for de få og hvilken avdeling som skal behandle hjerneslag.

\section{Yngve Müller Seljeseth \\ Petra Thiemann Vadset \\ Medisinsk avdeling}

\section{Janne Marit Ertresvåg}

Hans-Henrik Daae-Qvale

Nevrologisk avdeling

Ålesund sjukehus

Yngve Müller Seljeseth (f. 1974) er spesialist $\mathrm{i}$ indremedisin og geriatri og overlege ved

Medisinsk avdeling, seksjon for hjerneslag og geriatri. Han er medlem av Midtnorsk fagnettverk for hjerneslag, styringsgruppe LEASTstudien og av spesialistforeningen i geriatri. Ingen oppgitte interessekonflikter.

Petra Thiemann Vadset (f. 1966) er utdannet i Tyskland og har Jobbet i Norge siden 1998. Hun er godkjent spesialist $i$ indremedisin og i geriatri og er overlege ved seksjon for slagsykdommer og geriatri Helse Møre og Romsdal.

Ingen oppgitte interessekonflikter.

Janne Marit Ertresvåg (f. 1965) er spesialist i nevrologi og overlege ved Nevrologisk poliklinikk, Ålesund sjukehus fra 2006. Hun har tidligere arbeidet ved Nevrologisk avdeling St. Olav hospital.

Ingen oppgitte interessekonflikter.
Hans Henrik Daae-Qvale (f. 1950) er spesialist i fysikalsk medisin og rehabilitering og er under spesialisering i nevrologi. Han er konstituert overlege ved Nevrologisk avdeling. Ingen oppgitte interessekonflikter.

\section{Litteratur}

1. Waje-Andreassen U, Næss H, Kurz MW et al. Hjerneslag - nevrologi og tverrfaglighet. Tidsskr Nor Legeforen 2011; 131: 1873

2. Reichenbach A, Celius EG, Fure B et al. Hjerneslagbehandling - en tverrspesialisert utfordring Tidsskr Nor Legeforen 2011: 131: 934-6.

3. Lund CG. Hjerneslag krever spesialisert behandling. Tidsskr Nor Legeforen 2011: 131: 1874

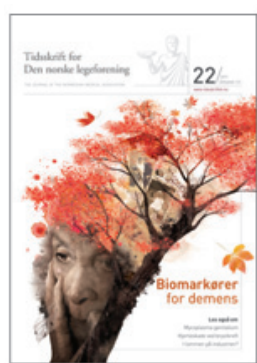

\section{Uavhengige forskningsmiljøer finnes!}

Vi har med interesse lest Robin Holtedahls kronikk i Tidsskriftet nr. 22/2011 (1).

Holtedahl beskriver en rekke tilfeller av økonomisk samrøre mellom industrien og ortopeder i USA når det gjelder leddproteser og ryggkirurgi. Holtedahl anfører at det er nødvendig med tett samarbeid mellom ortopedene og industrien for utvikling av nye ortopediske implantater, men at det må være full åpenhet og full transparens. Dette er vi selvsagt fullstendig enig med Holtedahl i.

Han avslutter sin kronikk med ønske om å bygge opp produsentuavhengige forskningsmiljøer. Det er da betimelig å minne om at vi i Norge har Nasjonalt register for leddproteser. Registeret for hofteproteser ble startet av norske ortopeder i 1987, fra 1994 ble leddproteser i andre ledd også inkludert. Senere har vi etablert Nasjonalt hoftebruddregister og Nasjonalt korsbåndsregister. Basert på frivillighet rapporterer norske ortopeder på standardisert skjema hver enkelt operasjon inn til registeret. Praktisk talt alle inngrep innen de nevnte kategorier blir meldt. Registrene finansieres av den norske stat gjennom Helse-Vest og Helse-Bergen og er altså økonomisk uavhengig av industrien. Registrene fungerer som en kontinuerlig overvåking av en stor del av den ortopediske kirurgien i Norge. Registrene har høstet nasjonal og internasjonal anerkjennelse og har en stor vitenskapelig produksjon (2).

Samarbeidet mellom registrene og implantatindustrien har vært uproblematisk i Norge. Leverandørene gir oss den informasjon vi trenger om implantatene de selger, 